\title{
Urgences
}

\section{Air mail}

\section{Marie Bélisle}

\section{Numéro 10, 2e trimestre 1984}

\section{Spécial fantasmes}

URI : https://id.erudit.org/iderudit/025157ar

DOI : https://doi.org/10.7202/025157ar

Aller au sommaire du numéro

\section{Éditeur(s)}

Urgences

\section{ISSN}

0226-9554 (imprimé)

1927-3924 (numérique)

Découvrir la revue

\section{Citer ce document}

Bélisle, M. (1984). Air mail. Urgences, (10), 65-73.

https://doi.org/10.7202/025157ar d'utilisation que vous pouvez consulter en ligne.

https://apropos.erudit.org/fr/usagers/politique-dutilisation/ 
MARIE BÉLISLE

AIR MAIL 
1.

les espaces liquides

salés acides microcosmes

transmettent réfractée l'onde

électrique

parfois captée par les sels d'argent

je te reconnais

(même)

immobile noir et blanc

(si l'océan I'alcool)

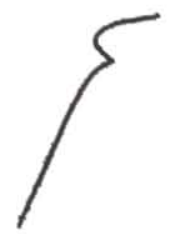


2.

quelques milliers de [pjeds plus bas

sous Jes atmosphères

l'eau'sais-tu combien 'de grains de' sel ' pour.ure larme.

atlantique 1

où logent'tes"passions

fugaces [

beliste
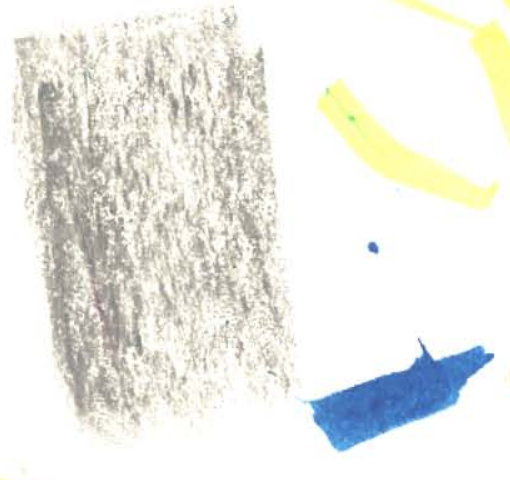

0

i

$-67-$

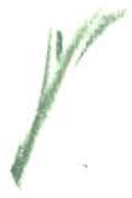


3.

persister t'attendre à contre-jour comme hier seulement derrière les verres noirs le soleil postée calme

(rien à déclarer) aux frontières 
4.

dis-moi entendais-tu les coulées

incertaines inquiètes de l'or l'acier dans mon sexe l'encre s'infiltrait sous tes paupières (alors) 
5.

demain

tu rompras les triangles scellant

ce petit aveu

bleu métal

noirci par les pointes

[patiente(s)] 
6.

un jour ce sera

bien après l'août I'hiver

mai sans doute j'irai

au bout des lignes tirées

(surgir entre les lames) 
7.

combien de kilomètres déjà décalés franchir bras et coeur tendus (71 battements/minute) sensible aux fréquences polaires bandes magnétiques
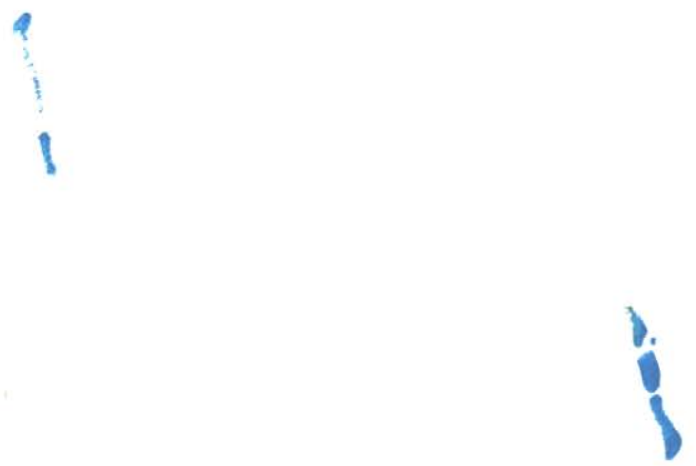
8.

quelqu'une son front s'étalant cherchant ce pays les épaules bien droites

(elle n'existe qu'à peine et malgré) le hasard ce sera

moi

t'appelant 